Journal of Tourism \& Hospitality Education

\title{
Tourism Potential of Plants Species Used for the Treatment of Malaria and Typhoid Fever in Omo Forest Reserve Southwest Nigeria
}

\author{
Francis Okosodo \\ Lecturer, Department of Leisure and Tourism Management, Federal Polytechnic, Illaro, Owen, Nigeria \\ francis.okosodo@federalpolyilaro.edu.ng \\ Sarada Prasad Mohapatra \\ Department of Botany N.C Autonomous college Jajpur, Odisha, India \\ bot.ncacjajpur@gmail.com
}

Article History

Received: 26 March 2021 Accepted: 20 May 2021

Keywords

Medicinal, plant species, malaria, typhoid fever, tourism, potentials
Corresponding Editor

Ramesh Raj Kunwar kunwar.dr@gmail.com
Abstract

This research study was carried out to investigate medicinal plant species that is used to treat malaria and typhoid fever and to provide information on the tourism potentials of these plants species in Omo forest reserve southwest Nigeria. The study area was divided into two compartments for the purpose of this research work, undisturbed forest and secondary forest compartments. Data was collected using field surveys and visiting traditional medicine homes for parts the used for the treatment of malaria and typhoid fever. Field trips were embarked upon for three months from July to September 2020 for medicinal plant species identification. The researchers were accompanied by a field assistant who can identify the plant species in local languages.. The computer PAST Model version 3 was used to analyze plant species diversity indices. The result obtained from the study shown that the study area is rich in plant species that are used to treat malaria and typhoid fever in southwest Nigeria. In all, a total of 81 plant species belonging to 42 families were recorded in the study area with great tourism potential when a sustainable management is set up. The family Asteraceae has a plant 
diversity of 6 and this is followed by Rubiaceae and Solanaceae family's which have five (5) each Figure 2. The diversity index was higher in the undisturbed compartment (4.414) than the secondary forest compartment (4.364).

\section{Introduction}

Medical tourism is the term commonly used to describe international travel to receive all care. Medical tourists may pursue medical care abroad for a variety of reasons, such as decreased cost, a recommendation from friends or family, the opportunity to combine medical care with a vacation destination, a preference for care from providers who share the traveler's culture, or to receive a procedure or therapy not available in their country of residence. Medical tourism is a worldwide, multibillion-dollar market that continues to grow (Hallmann et al, 2012).. Surveillance data indicate that millions of US residents travel internationally for medical care each year (Lipmann, et al, 2014). Ongoing reports of infections and other adverse events following medical or dental procedures abroad serve as reminders that medical tourism is not without risks. Nature has been a source of medicinal agents for thousands of years and an impressive number of modern drugs have been isolated from natural sources(Kazemi, M. 2013). Many of these isolations were based on the uses of the agents in traditional medicine, especially medicinal plants. Plants are usually the major component of traditional medicine (Global Initiative for Traditional Systems of Health, 2007, Schmincke, 2009; World Health Organization, 20013). With about $80 \%$ of the world's inhabitants relying mainly on traditional medicines for their primary health care, the traditional medical practice continues to play an essential role in health care. Traditional medicine is a principal form of health care for many populations, particularly in low- and middle-income countries where traditional healers are appealing since they share a common perspective with their clients, and make use of knowledge, beliefs, and practices indigenous to the local culture and also for its cost implication, the affordability of most traditional medicines makes them all the more attractive at a time of soaring health-care costs (WHO, 2013). This form of health care has continued to gain attention as an important means of health care coverage globally (Rokaya, et al, 2014). Malaria fever is one of the tropical diseases of socio-economic importance to which man have been looking for a solution for along time. It is the most prevalent of the tropical diseases identified as a threat to more than $40 \%$ of the world's population with about 200 to 450 million infections reported annually worldwide (Muriuki 2006, Adekunle, 2008). The annual death rate has been recorded at between 1.2 and 2.7. Its area of endemism covers more than 100 topical countries and its control remains a major concern for improved healthcare worldwide. The majority of malaria cases i.e about $90 \%$ are in sub-Saharan Africa and Plasmodium falciparum is the main cause of severe clinical malaria and eventual deaths Recently, many medical authorities like the world health organization (WHO) 
has come to recognize the place of herbal medicines as a viable alternative in the treatment of malaria infections. Since it mainly afflicts poor populations in the tropics, it attracts scant rewards for bioprospecting by big pharmaceutical companies for active molecules that could lead to new drugs. Whereas herbal antimalarial drug development based on traditional knowledge of plant use may hold more promise for developing countries' medicines. (WHO, 2014). Hence the relevance of this study investigated the indigenous use of plant species in the treatment of malaria and typhoid fever in the Omo forest reserve where the disease is prevalent. Thus this paper will highlights strategies and initiatives integrating tourism and botany for the purpose of knowledge transfer and education, with a specific emphasis on Omo forest reserve potential for developing herbal medicine-based tourism

\section{Literature review}

Tourism industry, as the biggest service industry in the world, has received much attention in the world. The majority of the developed or developing countries have considered tourism industry as their first economic priorities. Therefore, they plan to achieve to the highest rate of international tourism statistically. The phenomenon of tourism has developed over the last 50 years to become an enormous global industry nowadays (Ritchie and Crouch, 2000) and along with this a powerful economic source (Kayar and Kozak, 2007). These kinds of changes have led to massive tourism changes and in the near future, it will turn to qualitative tourism. Currently, tourism is a kind of strong and professional activity in the world. Tourism industry has developed substantially during the last 50 years and it has changed to an international major industry, which is regarded as the biggest economic source (Hallmann et al., 2012). Tourism is a kind of complex social and economic activity, which must be investigated at various levels to achieve the intended and organized development (Risteski et al., 2012). In order to design programs in tourism industry, we should consider various kinds of touris and their definitions. Since the demands and the required services are not at the same level for different types of tourists (Kazemi, 2006). Nowadays the countries that aim to increase their national gross income have considered tourism industry as an essential industry with the highest financial circulation, generative job creation, and great profits. Increase in the rate of international trips and getting interested in tourism destinations have branched out this term to some greed extent. Thus, there are various kinds of tourism such as religious tourism, sport tourism, war tourism, leisure tourism, medical Tourism, etc. Medicine tourism is considered as one of the most important kinds of tourism. Currently medical tourism has received industries (Connell, 2013). Zanjan city enjoys tremendous historical and natural tourism attractions it is a major tourism destination among tourists. Therefore, the improvement of medical services in terms of place and technical features plays essential role for economic development. In fact, when a health tourist utilizes the 
medicinal potentials of the city can be attracted to other types of tourism attractions and vice versa. Tourism can be classified and defined for various reasons but one of the most important groups can be medicinal touris

\section{Herbs and medicinal herb-based niche tourism}

Kala (2015) highlighted how medicinal and aromatic plants can create entrepreneurial opportunities, particularly in the tourism sector. Butthongdee (2015) indicated that community herbal learning centres in Thailand have the potential to become important tourist attractions. In addition, Deka,et, al, (2015) noted, and ecological benefits for rural communities through tourism In their study, herbal that the traditional use of herbal health remedies in India provides significant nutritional, economic gardens not only engage farmers in introducing home herb gardens but also enhanced a sense of familiarity with local biodiversity and its conservation, especially herbal plants. Establishing herb gardens was shown to create jobs in nearby villages, and results showed that people are interested in herbal medicine tourism. The Indian state of Kerala is well known for herbal tourism, especially for Ayurvedic treatment, and a large number of people visit India for herbal tourism; these herbal tourists provide employment for thousands of people (Sharma, 2013). In 2009, India received approximately 180,000 foreign tourists who came for health services such as yoga, meditation, herbal therapies, and skin treatments (Sharma, 2013). Dzida, et al, (2014) studied the opinions of potential recipients of agritourism services on the need for herb gardens and the possible use of herbal plants on a farm. The results illustrated that $89 \%$ of respondents recognize the importance of herb gardens in enhancing the attractiveness of agritourism farms. The results also indicated that for $91 \%$ of respondents, the possibility of using fresh herbs was appealing, providing a potential advantage for such enterprises. Most of Dzida et al's respondents believe that natural aromatherapy can be an important part of the offer on agritourism farms. Opinions on the usefulness of herbs on the farm were divided: $43 \%$ were of the opinion that these are spice plants, 33\% considered them medicinal plants, and $24 \%$ consider them ornamentals. Despite the growing recognition of herb-based tourism, there is a general lack of studies on the subject, and most recent studies emphasize herbal tourism as being part of health and wellness tourism (Nolan and Schneider, 2011), medical tourism (Chambers and McIntosh, 2008), or agritourism (Berdzenishvili, Abesadze, et al, 2013). However, none of these approaches take into consideration strategies and initiatives that can promote herbal medicine niche tourism specifically, nor do any of these tourisms consider medicinal herb tourism as an integrated niche form of tourism. Likewise, until now, no significant work has been undertaken on herbal medicine tourism to investigate innovative strategies for developing this niche in Iran. The importance of research on this topic will become more obvious when there is a significant increase in innovative strategies 
for promoting herbal medicine tourism in the Traditional Herbal Medicine Tourist Park, restaurants, teahouses, and wellness tourism centres of Isfahan and other cities in the future. Herbal medicine niche tourism as an integrated tourism Education and learning have become an increasingly important and recognized component of travel activity and travel experiences (Canadian Tourism Commission, 2001; Ritchie, Carr, and Cooper, 2003). Educational tourism has developed because of the growing population of travellers who have a formal education, the importance of education in motivating people to travel, and the growing popularity of formal teaching and learning outside the classroom environment.Travel for educational purposes can be a diverse and complicated area of study (Ritchie et al., 2003). According to some authors (Donaldson and Gatsinzi, 2005; Gogoi and Balaji, 2015; Ohe, et al, 2014), educational tourism has generated excitement from the tourism industry and is a lucrative market segment. Education or learning may be either the main reason for a trip or a secondary reasons that is perceived to be an important way of using leisure time (Canadian Tourism Commission, 2001; Ritchie et al., 2003). Educational tourism offers opportunities to travel and study overseas and outdoors (Benson, 2005).

Educational tourism is one of several niche tourism forms (scientific tourism and research tourism) that emphasize knowledge transfer and knowledge management. Museums are key components of educational tourism and are open for the purpose of conserving and preserving, studying, interpreting, assembling, and exhibiting objects and specimens of educational and cultural value to the public for their instruction and enjoyment (Ambrose and Paine, 2006). Botanical gardens, such as traditional herbal medicine tourist parks, are good examples of a sort of open-air museum (Benfield, 2013) that exhibits and educates about traditional medicine as places of intangible cultural heritage (ICH). Normally, in Persian culture, most soft medicinal plants are used in foods and served as tea and beverages in teahouses, restaurants, and hotels. For example, borage is very commonly associated with refreshing drinks; lemon verbena (Aloysia citrodora) tea is useful for relaxation and decreases depression and nervousness; saffron and mint teas are relaxing drinks with healthful benefits. However, most customers, tourists, and visitors who drink these teas or beverages are unfamiliar with the medicinal plants and their therapeutic properties. The establishment of a traditional herbal medicine tourist park in Isfahan, Iran, is being considered as an outdoor strategy for knowledge transfer and the popularization of traditional medicine, botany, and medicinal plants.

Knowledge transfer is also a crucial element of heritage tourism. Cultural heritage involves inherited objects, beliefs, practices, and activities from the past that are valued and used in the present (Timothy, 2011). Food, cuisine, and food ways are crucial elements of human heritage and tell many stories of nationalism, identity, migration, colonialism, faith, family, and humankind's struggles with nature 
(Mahachi-Chatibura, 2016; Timothy, 2016). In recognition of food as a heritage product, specific food types (e.g. spices, dishes, herbs, food preparation methods) are salient elements of the heritagescapes of tourist destinations and can function as primary attractions or as enhancers of a place's cultural brand (Jolliffe, 2014).

It has been estimated that in developed countries such as United States, plant drugs constitute as much as $25 \%$ of the total drugs, while in fast developing countries such as China and India, the contribution is as much as $80 \%$. Thus, the economic importance of medicinal plants is much more to countries such as India than to rest of the world (Monier and Abd, 2016). These countries provide two third of the plants used in modern system of medicine and the health care system of rural population depend on indigenous systems of medicine. More than one-tenth of plant species are used in drugs and health products, with more than 50,000 species being used. However, the distribution of medicinal plants is not uniform across the world (Cole, et al, 2007) For ex example, China and India have the highest numbers of medicinal plants used, with 11,146 and 7500 species, respectively, followed by Colombia, South Africa, the United States, and another 16 countries with percentages of medicinal plants ranging from $7 \%$ in Malaysia to $44 \%$ in India versus their total numbers of plant species (Hamilton2005, 2003 Marcy, 2005, Ratknić,et al, 2011)

. The use of traditional medicine in various therapies by the indigenous population over the world cannot be overemphasized, according to the World Health Organization (WHO, 2005) as many as $80 \%$ of the world's people depend on traditional medicine for their primary healthcare needs. Due to poverty, ignorance and unavailability of modern health facilities, most people especially rural people are still forced to practice traditional medicines for their common day ailments, most of these people form the poorest link in the trade of medicinal plants (Khan, 2002). A vast knowledge of how to use the plants against different illnesses may be expected to have accumulated in areas where the use of plants is still of great importance (Diallo et al.,2009). In the developed countries, 25 per cent of the medical drugs are based on plants and their derivatives (Principe, 2001).

During the past decade, traditional medicinal practices have become a topic of global relevance. In many developing nations, a significant number of indigenous populations rely on medicinal plants to meet their health care needs. According to Lewis and Elvin-Lewis (2003), botanically derived medicinal plants have played a major role in human societies throughout history and prehistory and people have used plants as medicine since the beginning of civilization, as they were believed to have healing powers (Connie and King, 2003). The use of plants in the tropical and subtropical regions is diversified and most of the uses are for medicine, source of food, clothing and shelter. But the medicinal uses of plants are rapidly declining among the present generation of local people as a consequence of modernization and 
civilization (Cox, 2005). The younger generation is showing little interest in learning this valuable science of healing. Usage of medicinal plants to cure diseases has also been much influenced by religious practices (Trease and Evans, 1989; Wambebe, 1999). All over the world, several ethnobotanical studies focusing on medicinal plants have been documented (Ekpendu et al., 1998; Balansard and Timon, 2000; Singh and (Cox, 2005; Kumar et al., 2005; Pei, 2005). But in Nigeria, very little information about ethnobotanical studies has been documented (Sofowora, 2013). Therefore the need for proper documentation of traditional medicinal practices among the people in Nigeria where there has been a dearth of published information is immediately called for and this accounts for the rationale to undertake the present study.

\section{Importance of medicinal plants}

Nature has been a source of medicinal agents for thousands of years and an impressive number of modern drugs have been isolated from natural sources. Many of these isolations were based on the uses of the agents in traditional medicine especially medicinal plants. Plants are usually the major component of traditional medicine (Global Initiative for Traditional Systems of (World Health Organization, 2003). From time immemorial, mankind has been developing a traditional medicinal system, based on the knowledge of medicinal plants throughout the world (Falodun, 2010; Petrovska, 2012) and these plants and their products have also continuously played important role in the health care systems; especially of the people living in developing countries (Pan et al., 2014; Harvey et al., 2015).

Historically, the use and practices of many traditional medicine, including experiences are passed on through oral information from generation to generation and such knowledge survives because it is transferred from one generation to another (Kayani et al., 2015; Ijaz et al., 2016). High emigration rates, exposure to modern culture, rapid land degradation, access to modern facilities and urban developmental processes altering the distribution of communities are affecting transformation of such knowledge, thus indigenous knowledge in this area is gradually (Amjad et al., 2017) eroding. There is therefore a strong need to conserve this valuable knowledge, in order to (i) preserve cultural heritage, (ii) to provide basis for ethnopharmacological drug research and (iii) to preserve our biological diversity. (Weldegerima, 2009)

Typhoid fever is a life-threatening systemic infection caused by the bacterium, Salmonella typhi. It is a global public health problem that is especially worse in the developing nations of the world where sanitation is deficient, (Rokaya et al., 2014) it is a significant contributor to morbidity and mortality in Nigeria and surrounding regions (Enabulele and Awunor, 2016). It is transmitted through the ingestion of food or drink contaminated by the faeces or urine of infected people (WHO, 2008). 


\section{Materials and method}

The study was carried out in Omo Forest Reserve which is situated between latitude 60 35' to 7 o $03^{\prime}$ North longitudes 04 o 9' to 04 o $40^{\prime}$ East in the southwestern part of Nigeria (Adesoye Ezenwenyi, 2014). The reserve is bounded by BeninShagamu expressway to the south and Omo River and Oni River to the east. The forest soils are dominantly ferralitic and highly weathered. The texture of the forest soil is usually loamy and sandy becoming heavier at greater depths, frequently with layers of gravel found between $30-60 \mathrm{~cm}$. The soils tend to be acidic with low cations exchange capacity. If the soils are not maintained under forest cover surface soil erosion would set in (Isichei, 2005). An annual rainfall of 2,000 $\mathrm{mm}$ and a dry season from November to March and wet season from April to November, with the rains falling almost every day during our survey (Mengistu, Salami 2007, Okosodo et al, 2016). The terrain is undulating with an elevation of about $300 \mathrm{~m}$ on some rocky hills. The areas south of the reserve are at lower elevations than those to the north (Adekunle, 2006). The pockets of primary forests are around inaccessible areas where timber extraction is impossible. In the logged areas, vines are tangled with the secondary growth forest dominated by Musanga cecropoides, and a few oil palm trees Elaeis guineensis compared to sites further west along the road to Lagos. Most remaining larger trees are the soft- wooded Cieba pentandra (Bombacaceae). Along the low-lying areas are drainages covered by tangled vegetation with few trees making access difficult. Cocoa farms now replace cleared areas of the forest (Okosodo, et al, 2016).

Figure 1: Map of the study area source: (Ezenwenyi and Onyekachi)

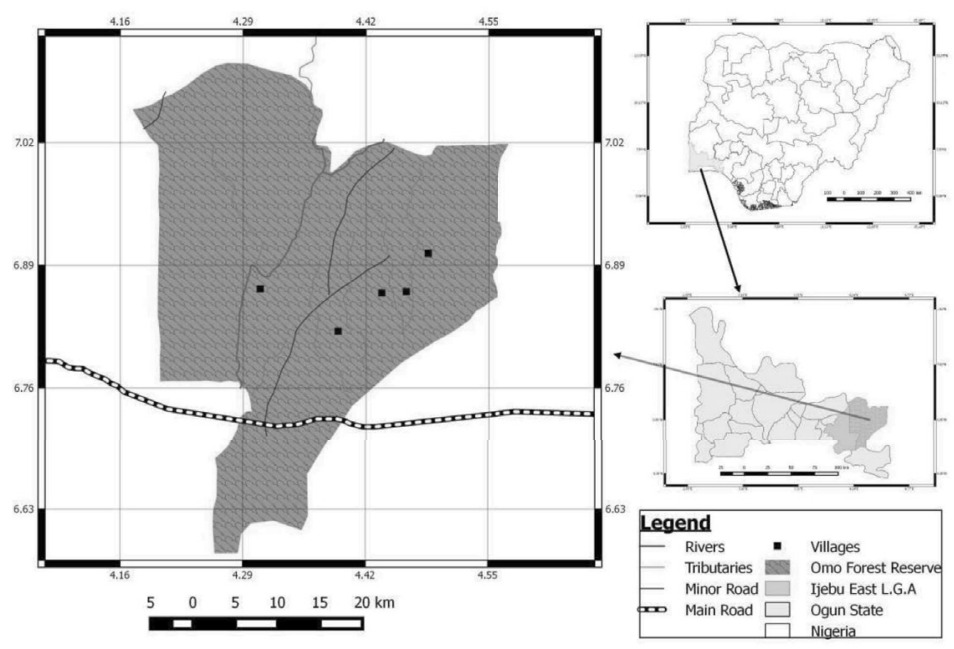




\section{Data collection}

The study was carried out in Omo forest reserve. The study area was divided into two compartments for the purpose of this research work, undisturbed forest and secondary forest compartments. Data was collected using field surveys and visiting traditional medicine homes for parts the used for the treatment of malaria and typhoid fever in (Igbarese and Ogbole 2018). Field trips were embarked upon for three months from August to September 2020 for medicinal plant species identification. The researchers were accompanied by a field assistant who can identify the plant species in local languages. Six popular and highly patronized traditional healing homes across the three villages surrounding the Omo forest reserve were visited. This was followed by direct observation and collections of herbal plants from the wild. The plants collected were identified by their vernacular names and their scientific equivalent found and documented. Identification of herbs as well as their uses was done with the aid of a book of the tress of Nigeria (Gbele and Soladoye, 2012) while the inventory of available herbs was recorded. The literature on medicinal plants was searched to back up the claims by the traditional practitioners. Also, parts of medicinal plants not readily identifiable were taken to the herbarium at the Department of Forestry and Wood technology, the Federal University of Technology Akure for proper identification. Plant parts mostly leaves were put in the press for proper preservation

\section{Statistical analysis}

Data obtained from the field survey were entered into Excel (version 15) spreadsheet before both descriptive (tables, frequency, and percentage frequency, graph, pie, and bar charts). The computer PAST Model version 3 was used to analyze plant species diversity indices,

\section{Results}

The result obtained from the study shown that the study area is rich in plant species that are used to treat malaria and typhoid fever in southwest Nigeria. In all, a total of 81 plant species belonging to 42 families were recorded in the study area. The family Asteraceae has a plant diversity of 6 and this is followed by Rubiaceae and Solanaceae family's which have five (5) each Figure 2. The diversity index was higher in the undisturbed compartment (4.414) than the secondary forest compartment (4.364) Table 1. Plant type that is used to treat malaria and typhoid fever indicates that tree species (56) more than the shrubs (25). Figure 3 The pats of the plant species used, the form either dry or fresh and mode it is used Table 2. Checklist of plants that win the was recorded in the study area Table 3 
Figure 2: The Family composition of ethnobotanical plant species in the study area

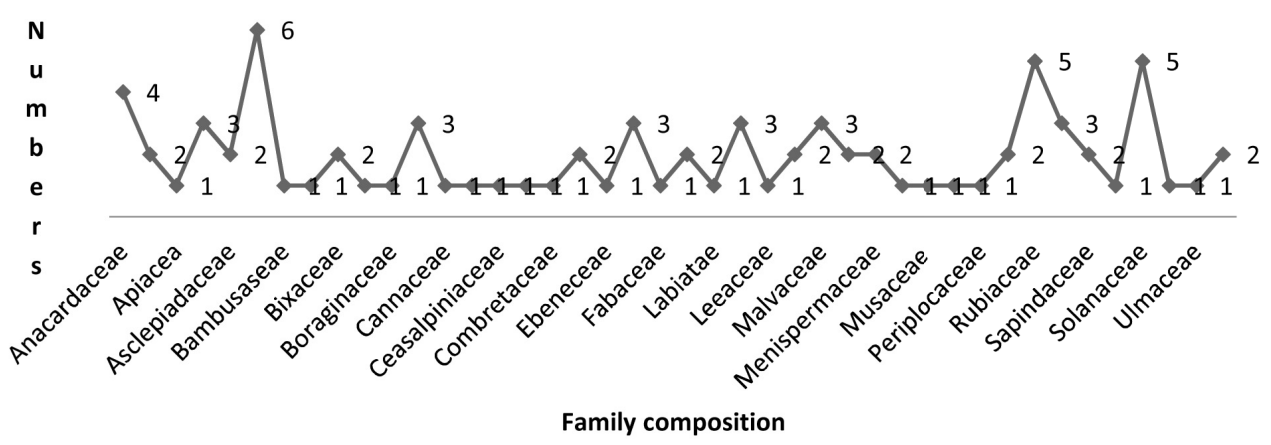

Table1: Diversity index plants species in the plots in the study area

\begin{tabular}{|c|c|c|c|c|c|c|}
\hline 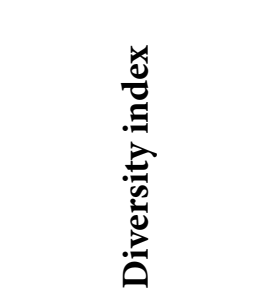 & 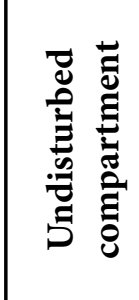 & 离 & 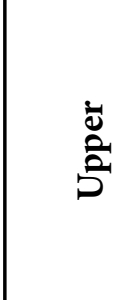 & 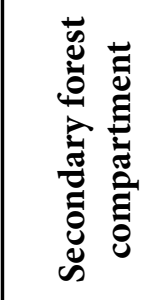 & 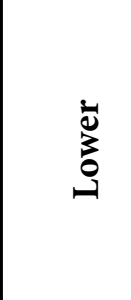 & $\begin{array}{l}\dot{\Xi} \\
\stackrel{0}{2}\end{array}$ \\
\hline Taxa_S & 84 & 56 & 68 & 84 & 56 & 69 \\
\hline Individuals & 88 & 88 & 88 & 94 & 94 & 94 \\
\hline Dominance_D & 0.0124 & 0.01756 & 0.02428 & 0.01426 & 0.01811 & 0.02784 \\
\hline Shannon_H & 4.414 & 3.887 & 4.138 & 4.364 & 3.844 & 4.128 \\
\hline Evenness_e $\mathrm{e}^{\wedge} \mathrm{H} / \mathrm{S}$ & 0.9836 & 0.8562 & 0.9295 & 0.9357 & 0.8101 & 0.913 \\
\hline Brillouin & 3.482 & 3.19 & 3.339 & 3.479 & 3.18 & 3.358 \\
\hline Menhinick & 8.954 & 5.97 & 7.249 & 8.664 & 5.776 & 7.117 \\
\hline Margalef & 18.54 & 12.28 & 14.96 & 18.27 & 12.11 & 14.97 \\
\hline Equitability_J & 0.9963 & 0.9619 & 0.9825 & 0.985 & 0.9484 & 0.9783 \\
\hline
\end{tabular}


Figure 3: Plant Type recorded in the study area

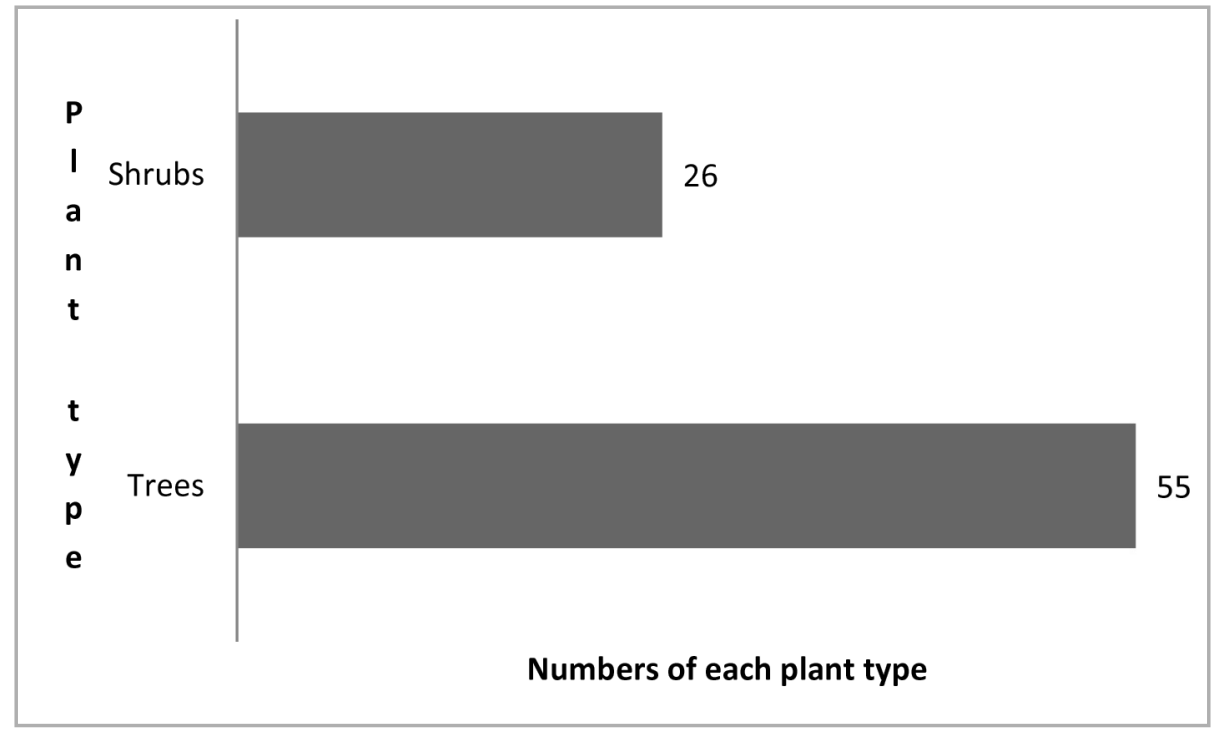

Table 2: Medicinal herbs, parts used, form and the mode of used

\begin{tabular}{|l|l|l|l|}
\hline \multicolumn{1}{|c|}{ Plant species name } & Parts used & $\begin{array}{c}\text { Form } \\
\text { used }\end{array}$ & \multicolumn{1}{|c|}{ Mode of use } \\
\hline $\begin{array}{l}\text { Acanthospermus } \\
\text { hispidum }\end{array}$ & leaves & Fresh & $\begin{array}{l}\text { Boil with khaya } \\
\text { seneganlensis, } \\
\text { and dry pawpaw leaves as } \\
\text { concoction }\end{array}$ \\
\hline Aframomum melegueta & Seeds & $\begin{array}{l}\text { Dried } \\
\text { seeds }\end{array}$ & $\begin{array}{l}\text { Boil with Anacardium } \\
\text { occidentale leaves, } \\
\text { Alcornea cordifolia leaves } \\
\text { used for vapor bathing }\end{array}$ \\
\hline Ageratum conyzoides & & Boil leaves is taken orally \\
\hline Alchornea cordifolia & Leaves & Fresh & $\begin{array}{l}\text { Boil with Alstonia boonei } \\
\text { bark and dry pawpaw } \\
\text { leaves as concoction }\end{array}$ \\
\hline Anacardium occidentale & $\begin{array}{l}\text { Leaves and } \\
\text { bark }\end{array}$ & $\begin{array}{l}\text { Fresh or } \\
\text { dried }\end{array}$ & $\begin{array}{l}\text { Leaves and bark boil with } \\
\text { leaves and mango }\end{array}$ \\
\hline
\end{tabular}




\begin{tabular}{|c|c|c|c|}
\hline Plant species name & Parts used & $\begin{array}{l}\text { Form } \\
\text { used }\end{array}$ & Mode of use \\
\hline Ananas comosus & $\begin{array}{l}\text { Leaves and } \\
\text { bark }\end{array}$ & $\begin{array}{l}\text { Fresh and } \\
\text { dry }\end{array}$ & $\begin{array}{l}\text { Boil leaves and bark } \\
\text { with leaves and fruits of } \\
\text { citrus lemon add drink as } \\
\text { concoction }\end{array}$ \\
\hline Alstonia boonei & $\begin{array}{l}\text { Leaves and } \\
\text { bark }\end{array}$ & $\begin{array}{l}\text { Fresh and } \\
\text { dry }\end{array}$ & $\begin{array}{l}\text { Squeeze fresh leaves in } \\
\text { water and drink the } \\
\text { extract. Dried leaves can } \\
\text { be cooked with soup } \\
\end{array}$ \\
\hline Aspilia africana & Leaves & Fresh & Boil with other herbs \\
\hline Bambusa vulgaris & Apex leaves & Fresh & $\begin{array}{l}\text { Squeeze fresh leaves in } \\
\text { water and drink the } \\
\text { extract. }\end{array}$ \\
\hline Blighia sapida & \begin{tabular}{|l} 
Leaves, \\
bark, and \\
roots
\end{tabular} & $\begin{array}{l}\text { Fresh and } \\
\text { dry }\end{array}$ & $\begin{array}{l}\text { Boil leaves and bark with } \\
\text { leaves, Dried leaves can } \\
\text { be cooked with soup }\end{array}$ \\
\hline Bridelia ferruginea & \begin{tabular}{|l|} 
Leaves, \\
bark,
\end{tabular} & $\begin{array}{l}\text { Fresh and } \\
\text { dry }\end{array}$ & \\
\hline Cajanus cajan & Leaves & $\begin{array}{l}\text { Fresh and } \\
\text { dry }\end{array}$ & $\begin{array}{l}\text { Boil with other herbs as } \\
\text { concoction }\end{array}$ \\
\hline Canna indica & Leaves & $\begin{array}{l}\text { Fresh and } \\
\text { dry }\end{array}$ & $\begin{array}{l}\text { Boil singly and drink the } \\
\text { extract }\end{array}$ \\
\hline Carica papaya & Leaves & $\begin{array}{l}\text { Fresh and } \\
\text { dry } \\
\end{array}$ & Boil with other herbs \\
\hline Capsicum frutescens & $\begin{array}{l}\text { Leaves and } \\
\text { fruits }\end{array}$ & $\begin{array}{l}\text { Fresh and } \\
\text { dry }\end{array}$ & $\begin{array}{l}\text { Boil with other herbs } \\
\text { and drink and use vapor } \\
\text { bathing }\end{array}$ \\
\hline Ceasalpinia bonduc & \begin{tabular}{|l|}
$\begin{array}{l}\text { Leaves, and } \\
\text { roots }\end{array}$ \\
\end{tabular} & $\begin{array}{l}\text { Fresh and } \\
\text { dry }\end{array}$ & $\begin{array}{l}\text { Cook leaves and roots } \\
\text { together and drink }\end{array}$ \\
\hline Cassia sieberiana & $\begin{array}{l}\text { Leaves, } \\
\text { flowers, } \\
\text { roots }\end{array}$ & Fresh & $\begin{array}{l}\text { Boil the leaves, bark and } \\
\text { flowers together and drink. } \\
\text { Also soak the bark and root } \\
\text { for } 8 \text { hours and drink }\end{array}$ \\
\hline Ceiba pentandra & Leaves & Fresh & $\begin{array}{l}\text { Boil with other herbs as } \\
\text { concoction }\end{array}$ \\
\hline
\end{tabular}




\begin{tabular}{|c|c|c|c|}
\hline Plant species name & Parts used & $\begin{array}{l}\text { Form } \\
\text { used }\end{array}$ & Mode of use \\
\hline Chromolaena odorata & Leaves & Fresh & $\begin{array}{l}\text { Boil with other herbs as } \\
\text { concoction }\end{array}$ \\
\hline Chorchoruso litorus & Leaves & Fresh & $\begin{array}{l}\text { Boil with other herbs as } \\
\text { concoction }\end{array}$ \\
\hline Chrysophyllum albidum & $\begin{array}{l}\text { Leaves, } \\
\text { bark, roots } \\
\text { and seeds }\end{array}$ & $\begin{array}{l}\text { Fresh and } \\
\text { dry }\end{array}$ & $\begin{array}{l}\text { Squeeze fresh leaves in } \\
\text { water and drink the } \\
\text { extract. Dried leaves can be } \\
\text { cooked with soup }\end{array}$ \\
\hline \begin{tabular}{|l|} 
Citrus medica \\
Citrus limon \\
\end{tabular} & \begin{tabular}{|l|}
$\begin{array}{l}\text { Leaves and } \\
\text { fruits }\end{array}$ \\
\end{tabular} & Fresh & $\begin{array}{l}\text { Boil singly and drink the } \\
\text { extract }\end{array}$ \\
\hline Citrus limon & $\begin{array}{l}\text { Leaves and } \\
\text { fruits }\end{array}$ & $\begin{array}{l}\text { Fresh and } \\
\text { dry }\end{array}$ & $\begin{array}{l}\text { Squeeze fresh leaves in } \\
\text { water and drink the } \\
\text { extract. Dried leaves can be } \\
\text { cooked with soup }\end{array}$ \\
\hline Citrus aurantifolia & $\begin{array}{l}\text { Leaves and } \\
\text { fruits }\end{array}$ & Fresh & $\begin{array}{l}\text { Cook with other herbs and } \\
\text { drink the . concoction }\end{array}$ \\
\hline $\begin{array}{l}\text { Cochlospermum } \\
\text { tinctorium }\end{array}$ & $\begin{array}{l}\text { Leaves and } \\
\text { seeds }\end{array}$ & $\begin{array}{l}\text { Fresh and } \\
\text { dry }\end{array}$ & $\begin{array}{l}\text { Squeeze fresh leaves in } \\
\text { water and drink the } \\
\text { extract. Dried leaves can be } \\
\text { cooked with soup }\end{array}$ \\
\hline Cola latertia & Leaves & $\begin{array}{l}\text { Fresh and } \\
\text { dry }\end{array}$ & $\begin{array}{l}\text { Boil with other herbs as } \\
\text { concoction }\end{array}$ \\
\hline Combretum reticulatum & Leaves & $\begin{array}{l}\text { Fresh and } \\
\text { dry }\end{array}$ & $\begin{array}{l}\text { Squeeze fresh leaves in } \\
\text { water and drink the } \\
\text { extract. Dried leaves can be } \\
\text { cooked with soup }\end{array}$ \\
\hline Curcuma longa & Fruits & $\begin{array}{l}\text { Fresh and } \\
\text { dry }\end{array}$ & $\begin{array}{l}\text { Boil singly and drink the } \\
\text { extract }\end{array}$ \\
\hline Cymbopogon citratus & Leaves & $\begin{array}{l}\text { Fresh and } \\
\text { dry }\end{array}$ & $\begin{array}{l}\text { Boil singly and drink the } \\
\text { extract }\end{array}$ \\
\hline Daucus carota & Leaves & $\begin{array}{l}\text { Fresh and } \\
\text { dry }\end{array}$ & $\begin{array}{l}\text { Boil singly and drink the } \\
\text { extract }\end{array}$ \\
\hline Diospyros mespiliformis & Leaves & $\begin{array}{l}\text { Fresh and } \\
\text { dry }\end{array}$ & $\begin{array}{l}\text { Boil singly and drink the } \\
\text { extract }\end{array}$ \\
\hline
\end{tabular}




\begin{tabular}{|c|c|c|c|}
\hline Plant species name & Parts used & $\begin{array}{l}\text { Form } \\
\text { used }\end{array}$ & Mode of use \\
\hline Emilia sonchifolia & Leaves & $\begin{array}{l}\text { Fresh and } \\
\text { dry }\end{array}$ & $\begin{array}{l}\text { Boil with other } \\
\text { ingredients and drink }\end{array}$ \\
\hline Euphorbia hirta & Leaves & Fresh & $\begin{array}{l}\text { Boil singly and drink the } \\
\text { extract }\end{array}$ \\
\hline Funtumia africana & Leaves & Fresh & $\begin{array}{l}\text { Boil singly and drink the } \\
\text { extract }\end{array}$ \\
\hline Garcinia kola & \begin{tabular}{|l} 
Leaves, \\
bark, fruits, \\
and roots \\
\end{tabular} & $\begin{array}{l}\text { Fresh and } \\
\text { Dry }\end{array}$ & $\begin{array}{l}\text { Boil singly and drink the } \\
\text { extract. }\end{array}$ \\
\hline Gongronema latifolia & Leaves & Fresh & $\begin{array}{l}\text { Boil singly and drink the } \\
\text { extract. }\end{array}$ \\
\hline Gossypium barbadens & $\begin{array}{l}\text { Leaves and } \\
\text { roots }\end{array}$ & Fresh & $\begin{array}{l}\text { Boil singly and drink the } \\
\text { extract. }\end{array}$ \\
\hline Gossypium hirsutum & $\begin{array}{l}\text { Leaves and } \\
\text { roots }\end{array}$ & $\begin{array}{l}\text { Fresh and } \\
\text { Dry }\end{array}$ & $\begin{array}{l}\text { Boil singly and drink the } \\
\text { Extract, Also the roots in } \\
\text { water for } 12 \text { hours and } \\
\text { drink or use to bath }\end{array}$ \\
\hline Haematostaphis barteri & Leaves & $\begin{array}{l}\text { Fresh and } \\
\text { Dry } \\
\end{array}$ & $\begin{array}{l}\text { Boil singly and drink the } \\
\text { extract }\end{array}$ \\
\hline $\begin{array}{l}\text { Harungana } \\
\text { madagascariensi }\end{array}$ & Leaves & $\begin{array}{l}\text { Fresh and } \\
\text { Dry }\end{array}$ & $\begin{array}{l}\text { Boil singly and drink the } \\
\text { extract }\end{array}$ \\
\hline Heliotropium indicum & Leaves & \begin{tabular}{|l} 
Fresh and \\
Dry \\
\end{tabular} & $\begin{array}{l}\text { Boil singly and drink the } \\
\text { extract }\end{array}$ \\
\hline Hyptis suaveolens & Leaves & \begin{tabular}{|l|} 
Fresh and \\
Dry \\
\end{tabular} & $\begin{array}{l}\text { Boil with cashew leaves } \\
\text { and drink the concoction }\end{array}$ \\
\hline Khaya senegalensis & $\begin{array}{l}\begin{array}{l}\text { Leaves, bark } \\
\text { and roots }\end{array} \\
\end{array}$ & \begin{tabular}{|l|} 
Fresh and \\
Dry \\
\end{tabular} & $\begin{array}{l}\text { Boil singly and drink the } \\
\text { extract }\end{array}$ \\
\hline Khaya senegalensis & $\begin{array}{l}\text { Leaves, bark } \\
\text { and roots }\end{array}$ & $\begin{array}{l}\text { Fresh and } \\
\text { Dry } \\
\end{array}$ & $\begin{array}{l}\text { Boil singly and drink the } \\
\text { extract }\end{array}$ \\
\hline Leea guineensis & \begin{tabular}{|l|}
$\begin{array}{l}\text { Leaves and } \\
\text { bark }\end{array}$ \\
\end{tabular} & \begin{tabular}{|l|} 
Fresh and \\
Dry \\
\end{tabular} & $\begin{array}{l}\text { Boil with cashew leaves } \\
\text { and drink the concoction }\end{array}$ \\
\hline Mangifera indica & $\begin{array}{l}\text { Leaves and } \\
\text { bark }\end{array}$ & $\begin{array}{l}\text { Fresh and } \\
\text { Dry }\end{array}$ & $\begin{array}{l}\text { Boil with cashew leaves } \\
\text { and drink the concoction }\end{array}$ \\
\hline
\end{tabular}




\begin{tabular}{|c|c|c|c|}
\hline Plant species name & Parts used & $\begin{array}{l}\text { Form } \\
\text { used }\end{array}$ & Mode of use \\
\hline Mitragyna inermis & Leaves & $\begin{array}{l}\text { Fresh and } \\
\text { Dry }\end{array}$ & $\begin{array}{l}\text { Boil singly and drink the } \\
\text { extract }\end{array}$ \\
\hline Morinda lucida & Leaves & $\begin{array}{l}\text { Fresh and } \\
\text { Dry }\end{array}$ & $\begin{array}{l}\text { Squeeze the leaves in } \\
\text { water and drink the } \\
\text { extracts. } 2 \text {.cook with } \\
\text { other herbs and drink as } \\
\text { concoction. }\end{array}$ \\
\hline Musa paradisiaca & Fruits & Fresh & $\begin{array}{l}\text { Boil singly and drink the } \\
\text { extract }\end{array}$ \\
\hline Musa sapientum & Fruits & Fresh & $\begin{array}{l}\text { Boil singly and drink the } \\
\text { extract }\end{array}$ \\
\hline Nauclea latifolia & Leaves & $\begin{array}{l}\text { Fresh and } \\
\text { Dry }\end{array}$ & $\begin{array}{l}\text { Boil with pap water and } \\
\text { drink the extracts }\end{array}$ \\
\hline Newbouldia laevis & Leaves & $\begin{array}{l}\text { Fresh and } \\
\text { Dry } \\
\end{array}$ & $\begin{array}{l}\text { Boil singly and drink the } \\
\text { extract }\end{array}$ \\
\hline Nicotiana tobacum & Laves & $\begin{array}{l}\text { Fresh and } \\
\text { Dry }\end{array}$ & $\begin{array}{l}\text { Squeeze fresh leaves in } \\
\text { water and drink the } \\
\text { extract. Dried leaves can be } \\
\text { cooked with soup }\end{array}$ \\
\hline Ocimum basilicum & Leaves & $\begin{array}{l}\text { Fresh and } \\
\text { Dry }\end{array}$ & $\begin{array}{l}\text { Squeeze fresh leaves in } \\
\text { water and drink the } \\
\text { extract. Dried leaves can be } \\
\text { cooked with soup }\end{array}$ \\
\hline Ocimum gratissimum & Leaves & $\begin{array}{l}\text { Fresh and } \\
\text { Dry }\end{array}$ & $\begin{array}{l}\text { Squeeze fresh leaves in } \\
\text { water and drink the } \\
\text { extract. Dried leaves can be } \\
\text { cooked with soup }\end{array}$ \\
\hline Parquetina nigrescens & Leaves & $\begin{array}{l}\text { Fresh and } \\
\text { Dry }\end{array}$ & $\begin{array}{l}\text { Squeeze fresh leaves in } \\
\text { water and drink the } \\
\text { extract. Dried leaves can be } \\
\text { cooked with soup }\end{array}$ \\
\hline
\end{tabular}




\begin{tabular}{|c|c|c|c|}
\hline Plant species name & Parts used & $\begin{array}{l}\text { Form } \\
\text { used }\end{array}$ & Mode of use \\
\hline Parquetina nigrescens & Leaves & $\begin{array}{l}\text { Fresh and } \\
\text { Dry }\end{array}$ & $\begin{array}{l}\text { Squeeze fresh leaves in } \\
\text { water and drink the } \\
\text { extract. Dried leaves can be } \\
\text { cooked with soup }\end{array}$ \\
\hline Paullinia pinnata & Leaves & $\begin{array}{l}\text { Fresh and } \\
\text { Dry }\end{array}$ & $\begin{array}{l}\text { Squeeze fresh leaves in } \\
\text { water and drink the } \\
\text { extract. Dried leaves can be } \\
\text { cooked with soup }\end{array}$ \\
\hline Pennisetum purpureum & Leaves & Fresh & $\begin{array}{l}\text { Boil singly and drink the } \\
\text { extract }\end{array}$ \\
\hline Pergularia daemi & Leaves & Fresh & $\begin{array}{l}\text { Boil singly and drink the } \\
\text { extract }\end{array}$ \\
\hline Piliostigma thonningii & Leaves & $\begin{array}{l}\text { Fresh and } \\
\text { Dry } \\
\end{array}$ & $\begin{array}{l}\text { Boil singly and drink the } \\
\text { extract }\end{array}$ \\
\hline Pseudocedrella kotschyi & Leaves & $\begin{array}{l}\text { Fresh and } \\
\text { Dry }\end{array}$ & $\begin{array}{l}\text { Squeeze the leaves in } \\
\text { water and drink the } \\
\text { extracts. }\end{array}$ \\
\hline Pycnanthus angolensis & $\begin{array}{l}\text { Leaves and } \\
\text { bark }\end{array}$ & $\begin{array}{l}\text { Fresh and } \\
\text { Dry }\end{array}$ & $\begin{array}{l}\text { Squeeze the leaves in } \\
\text { water and drink the } \\
\text { extracts. Squeeze dry leaves } \\
\text { inn a soup eat }\end{array}$ \\
\hline Physalis angulata & $\begin{array}{l}\text { Leaves and } \\
\text { seeds }\end{array}$ & $\begin{array}{l}\text { Fresh and } \\
\text { Dry }\end{array}$ & $\begin{array}{l}\text { Squeeze the leaves in } \\
\text { water and drink the } \\
\text { extracts. Soak the dry } \\
\text { leaves in palmwine for } 6 \\
\text { hours and drink }\end{array}$ \\
\hline Rauvolfia vomitoria & $\begin{array}{l}\text { Leaves, bark } \\
\text { and root }\end{array}$ & $\begin{array}{l}\text { Fresh and } \\
\text { Dry }\end{array}$ & $\begin{array}{l}\text { Squeeze the leaves in } \\
\text { water and drink the } \\
\text { extracts. Soak the dry } \\
\text { leaves in palmwine for } 6 \\
\text { hours and drink }\end{array}$ \\
\hline Sarcocephalus latifolius & Leaves & $\begin{array}{l}\text { Fresh and } \\
\text { Dry }\end{array}$ & $\begin{array}{l}\text { Boil the fresh leaves or dry } \\
\text { leaves in } \\
\text { water and drink }\end{array}$ \\
\hline
\end{tabular}




\begin{tabular}{|c|c|c|c|}
\hline Plant species name & Parts used & $\begin{array}{l}\text { Form } \\
\text { used }\end{array}$ & Mode of use \\
\hline Senna podocarpa & $\begin{array}{l}\text { Leaves and } \\
\text { seeds }\end{array}$ & $\begin{array}{l}\text { Fresh and } \\
\text { Dry }\end{array}$ & $\begin{array}{l}\text { Boil singly and drink the } \\
\text { extract }\end{array}$ \\
\hline Senna siamea & $\begin{array}{l}\text { Leaves and } \\
\text { flowers }\end{array}$ & $\begin{array}{l}\text { Fresh and } \\
\text { Dry }\end{array}$ & $\begin{array}{l}\text { Cook with Xylopia } \\
\text { ethiopica leaves and seeds } \\
\text { and drink when hot }\end{array}$ \\
\hline Sida acuta & Leaves & Fresh & $\begin{array}{l}\text { Boil the fresh leaves in } \\
\text { water and drink }\end{array}$ \\
\hline Solanum lycopersicon & Fruits & Fresh & $\begin{array}{l}\text { Boil singly and drink the } \\
\text { extract }\end{array}$ \\
\hline Solanum nigrum & \begin{tabular}{|l|}
$\begin{array}{l}\text { Leaves and } \\
\text { fruits }\end{array}$ \\
\end{tabular} & Fresh & $\begin{array}{l}\text { Boil with pap water and } \\
\text { drink the extracts }\end{array}$ \\
\hline $\begin{array}{l}\text { Sphenocentrum } \\
\text { jollyanum }\end{array}$ & Leaves & $\begin{array}{l}\text { Fresh and } \\
\text { Dry }\end{array}$ & $\begin{array}{l}\text { Boil with pap water and } \\
\text { drink the extracts }\end{array}$ \\
\hline Synclisia scabrida & Leaves & $\begin{array}{l}\text { Fresh and } \\
\text { Dry } \\
\end{array}$ & $\begin{array}{l}\text { Soak in water for } 8 \text { hours } \\
\text { drink the extract. }\end{array}$ \\
\hline Trema orientalis & Leaves & $\begin{array}{l}\text { Fresh and } \\
\text { Dry } \\
\end{array}$ & $\begin{array}{l}\text { Boil with pap water and } \\
\text { drink the extracts. }\end{array}$ \\
\hline Tithonia diversifolia & Leaves & $\begin{array}{l}\text { Fresh and } \\
\text { Dry }\end{array}$ & $\begin{array}{l}\text { Soak in water or pap water } \\
\text { for } 8 \text { hours and drink the } \\
\text { extract }\end{array}$ \\
\hline Vernonia amygdalina & Leaves & $\begin{array}{l}\text { Fresh and } \\
\text { Dry }\end{array}$ & $\begin{array}{l}\text { Soak in water or pap water } \\
\text { for } 8 \text { hours and drink the } \\
\text { extract }\end{array}$ \\
\hline Vigneasu bterranea & Leaves & $\begin{array}{l}\text { Fresh and } \\
\text { Dry }\end{array}$ & $\begin{array}{l}\text { Boil singly and drink the } \\
\text { extract }\end{array}$ \\
\hline Xylopia aethiopica & $\begin{array}{l}\text { Leaves and } \\
\text { seeds }\end{array}$ & $\begin{array}{l}\text { Fresh and } \\
\text { Dry }\end{array}$ & $\begin{array}{l}\text { Cook with other herbs and } \\
\text { add pepper and fish and } \\
\text { drink when hot }\end{array}$ \\
\hline
\end{tabular}


Table 3, Checklist of Ethnobotanical plant species in the study area

\begin{tabular}{|c|c|c|c|}
\hline $\begin{array}{c}\text { Name of Plant } \\
\text { Species }\end{array}$ & Family & Parts used & Uses \\
\hline $\begin{array}{l}\text { Acanthospermus } \\
\text { hispidum }\end{array}$ & Compositae & Leaves & $\begin{array}{l}\text { Malaria, Typhoid } \\
\text { fever }\end{array}$ \\
\hline $\begin{array}{l}\text { Aframomum } \\
\text { melegueta }\end{array}$ & Zingiberaceae & Seed & Malaria \\
\hline Ageratum conyzoides & Asteraceae & Leaves & Malaria \\
\hline Alchornea cordifolia & Euphorbiaceae & Leaves & $\begin{array}{l}\text { Malaria, Typhoid } \\
\text { fever }\end{array}$ \\
\hline $\begin{array}{l}\text { Anacardium } \\
\text { occidentale }\end{array}$ & Anacardiaceae & Leaves and bark & \\
\hline Ananas comosus & Anacardiaceae & Leaves & Malaria \\
\hline Alstonia boonei & Apocynaceae & Leaves and bark & $\begin{array}{l}\text { Malaria, Typhoid } \\
\text { fever }\end{array}$ \\
\hline Aspilia africana & Asteraceae & Leaves and bark & Malaria \\
\hline Bambusa vulgaris & Bambusaseae & Aex shoots & Malaria \\
\hline Blighia sapida & Sapindaceae & $\begin{array}{l}\text { Leaves, bark } \\
\text { and roo }\end{array}$ & Malaria \\
\hline Bridelia ferruginea & Euphorbiaceae & $\begin{array}{l}\text { Leaves and } \\
\text { bark, roots }\end{array}$ & Malaria \\
\hline Cajanus cajan & Fabaceae & Leaves & Malaria \\
\hline Canna indica & Cannaceae & Leaves & $\begin{array}{l}\text { Malaria, Typhoid } \\
\text { fever }\end{array}$ \\
\hline Carica papaya & Caricaceae & Leaves & $\begin{array}{l}\text { Malaria, Typhoid } \\
\text { fever }\end{array}$ \\
\hline Capsicum frutescens & Solanaceae & $\begin{array}{l}\text { Leaves and } \\
\text { fruits }\end{array}$ & Malaria \\
\hline Ceasalpinia bonduc & Ceasalpiniaceae & $\begin{array}{l}\text { Leaves and } \\
\text { roots }\end{array}$ & Typhoid \\
\hline Cassia sieberiana & Asteraceae & Leaves and bark & Malaria \\
\hline Ceiba pentandra & Bombacaceae & Leaves & Typhoid \\
\hline Chromolaena odorata & Leguminosae & Leaves & Malaria \\
\hline Chorchoruso litorus & Bixaceae & Leaves & Malaria \\
\hline
\end{tabular}




\begin{tabular}{|l|l|l|l|}
\hline \multicolumn{1}{|c|}{$\begin{array}{c}\text { Name of Plant } \\
\text { Species }\end{array}$} & \multicolumn{1}{|c|}{ Family } & \multicolumn{1}{c|}{ Parts used } & \multicolumn{1}{c|}{ Uses } \\
\hline $\begin{array}{l}\text { Chrysophyllum } \\
\text { lbidum }\end{array}$ & Sapotaceae & Typhoid \\
\hline Citrus medica & Rutaceae & $\begin{array}{l}\text { Leaves and } \\
\text { fruits }\end{array}$ & Typhoid \\
\hline Citrus limon & Rutaceae & $\begin{array}{l}\text { Leaves and } \\
\text { fruits }\end{array}$ & Malaria \\
\hline Citrus aurantifolia & Rutaceae & $\begin{array}{l}\text { Leaves and } \\
\text { fruits }\end{array}$ & $\begin{array}{l}\text { Malaria, Typhoid } \\
\text { fever }\end{array}$ \\
\hline $\begin{array}{l}\text { Cochlospermum } \\
\text { tinctorium }\end{array}$ & Bixaceae & Leaves & Malaria \\
\hline Cola latertia & Sterculiceae & Leaves & Malaria \\
\hline $\begin{array}{l}\text { Combretum } \\
\text { reticulatum }\end{array}$ & Combretaceae & $\begin{array}{l}\text { Leaves and } \\
\text { seeds }\end{array}$ & Malaria \\
\hline Curcuma longa & Zingiberaceae & fruit & Malaria \\
\hline Cymbopogon citratus & Poaceae & Leaves & Malaria \\
\hline Daucus carota & Apiacea & Leaves & Malaria \\
\hline $\begin{array}{l}\text { Diospyros } \\
\text { mespiliformis }\end{array}$ & Ebeneceae & Leaves & Malaria \\
\hline Emilia sonchifolia & Asteraceae & Leaves & $\begin{array}{l}\text { Malaria Typhiod } \\
\text { fever }\end{array}$ \\
\hline Euphorbia hirta & Euphorbiaceae & Leaves & Malaria \\
\hline Funtumia africana & Apocynaceae & Leaves & Malaria \\
\hline Garcinia kola & Clusiaceae & $\begin{array}{l}\text { Leaves and } \\
\text { fruits }\end{array}$ & $\begin{array}{l}\text { Malaria Typhoid } \\
\text { fever }\end{array}$ \\
\hline Gongronema latifolia & Asclepiadaceae & Leaves & Malria \\
\hline $\begin{array}{l}\text { Gossypium } \\
\text { barbadens }\end{array}$ & Malvaceae & $\begin{array}{l}\text { Leaves and } \\
\text { roots }\end{array}$ & $\begin{array}{l}\text { Malaria, Typhoid } \\
\text { fever }\end{array}$ \\
\hline Gossypium hirsutum & Malvaceae & $\begin{array}{l}\text { Leaves and } \\
\text { roots }\end{array}$ & Malaria \\
\hline $\begin{array}{l}\text { Haematostaphis } \\
\text { barteri }\end{array}$ & Anacardiaceae & Leaves & Malaria \\
\hline $\begin{array}{l}\text { Harungana } \\
\text { madagascariensi }\end{array}$ & Hypericaceae & Leaves & Malaria \\
\hline
\end{tabular}




\begin{tabular}{|l|l|l|l|}
\hline \multicolumn{1}{|c|}{$\begin{array}{c}\text { Name of Plant } \\
\text { Species }\end{array}$} & \multicolumn{1}{|c|}{ Family } & \multicolumn{1}{c|}{ Parts used } & \multicolumn{1}{c|}{ Uses } \\
\hline $\begin{array}{l}\text { Harunganamada } \\
\text { gascariensis }\end{array}$ & Hypericaceae & Leaves & Malaria \\
\hline $\begin{array}{l}\text { Heliotropium } \\
\text { indicum }\end{array}$ & Boraginaceae & Leaves & Malaria \\
\hline Hyptis suaveolens & Labiatae & Leaves & Malaria \\
\hline Khaya senegalensis & Meliaceae & Leaves and bark & Typhoid \\
\hline Khaya senegalensis & Meliaceae & $\begin{array}{l}\text { Leaves, bark } \\
\text { and roots }\end{array}$ & Typhoid \\
\hline Leea guineensis & Leeaceae & Leaves and bark & Typhoid \\
\hline Mangifera indica & Anacardaceae & Leaves and bark & $\begin{array}{l}\text { Malria Typhoid } \\
\text { Fever }\end{array}$ \\
\hline Melicia excelsa & Moraceae & Leaves and bark & $\begin{array}{l}\text { Malria Typhoid } \\
\text { Fever }\end{array}$ \\
\hline Mitragyna inermis & Rubiaceae & Leaves & Malria \\
\hline Morinda lucida & Rubiaceae & Leaves & Malaria \\
\hline Musa paradisiaca & Musaceae & Leaves & Malaria \\
\hline Monadora myristica & Annonaceae & $\begin{array}{l}\text { Leaves and } \\
\text { seeds }\end{array}$ & $\begin{array}{l}\text { Malaria, Typhoid } \\
\text { fever }\end{array}$ \\
\hline Musa sapientum & Asteraceae & unripe fruits & Malaria \\
\hline Nauclea latifolia & Rubiacea & Leaves & Malaria \\
\hline Newbouldia laevis & Bignonaceae & Leaves & Malaria \\
\hline Nicotiana tobacum & Solanaceae & Leaves & Malaria \\
\hline Ocimum basilicum & Lamiaceae & Leaves & Malaria \\
\hline Ocimum gratissimum & Lamiaceae & Leaves & Malaria \\
\hline Parquetina nigrescens & Lamiaceae & Leaves & Malaria \\
\hline Parquetina nigrescens & Periplocaceae & Leaves & Malaria \\
\hline Paullinia pinnata & Sapindaceae & Leaves & Malaria \\
\hline $\begin{array}{l}\text { Pennisetum } \\
\text { purpureum }\end{array}$ & Poaceae & Leaves & Malaria \\
\hline Pergularia daemi & Asclepiadaceae & Leaves & Malaria \\
\hline $\begin{array}{l}\text { Piliostigma } \\
\text { thonningii }\end{array}$ & Caesalpinaceae & Leaves & Malaria \\
\hline
\end{tabular}




\begin{tabular}{|l|l|l|l|}
\hline \multicolumn{1}{|c|}{$\begin{array}{c}\text { Name of Plant } \\
\text { Species }\end{array}$} & \multicolumn{1}{|c|}{ Family } & \multicolumn{1}{c|}{ Parts used } & \multicolumn{1}{c|}{ Uses } \\
\hline $\begin{array}{l}\text { Pseudocedrella } \\
\text { kotschyi }\end{array}$ & Rubiacea & Leaves & Malaria \\
\hline $\begin{array}{l}\text { Pycnanthus } \\
\text { angolensis }\end{array}$ & Myristicaceae & Leaves & Malaria \\
\hline Physalis angulata & Solanaceae & $\begin{array}{l}\text { Leaves and } \\
\text { seeds }\end{array}$ & Malaria \\
\hline Rauvolfia vomitoria & Apocynaceae & Leaves & Malaria \\
\hline $\begin{array}{l}\text { Sarcocephalus } \\
\text { latifolius }\end{array}$ & Rubiaceae & Leaves & Malaria \\
\hline Senna podocarpa & Caesalpiniaceae & $\begin{array}{l}\text { Leaves and } \\
\text { flowers }\end{array}$ & Malaria, \\
\hline Senna siamea & Caesalpiniaceae & Leaves & Malaria \\
\hline Sida acuta & Malvaceae & Leaves & Malaria \\
\hline Solanum lycopersicon & Solanaceae & Fruits & Malaria \\
\hline Solanum nigrum & Solanaceae & $\begin{array}{l}\text { Leaves and } \\
\text { fruits }\end{array}$ & Malaria \\
\hline $\begin{array}{l}\text { Sphenocentrum } \\
\text { jollyanum }\end{array}$ & Menispermaceae & Leaves & Malaria \\
\hline Synclisia scabrida & Menispermaceae & Leaves & Malaria \\
\hline Trema orientalis & Ulmaceae & Leaves & Malaria \\
\hline Tithonia diversifolia & Compositae & Leaves & $\begin{array}{l}\text { Malaria, Typhoid } \\
\text { fever }\end{array}$ \\
\hline Vernonia amygdalina & Asteraceae & Leaves & $\begin{array}{l}\text { Malaria, Typhoid } \\
\text { fever }\end{array}$ \\
\hline Vigneasu bterranea & Asteraceae & Leaves & $\begin{array}{l}\text { Malaria, Typhoid } \\
\text { fever }\end{array}$ \\
\hline Xylopia aethiopica & Annonaceae & seeds & Malaria \\
\hline
\end{tabular}

\section{Discussion}

The result obtained indicates that the study area is rich pant species that is used to treat malaria fever and typhoid in southwest Nigeria. In all, a total of eighty-one (81) Plant species belonging to 41 families was recorded in the study area. These findings consist of other studies such as (Sodipo, and Wannang, 2015). on the use of forest plants to treat some tropical diseases. 
It is also consistent with the work of several researchers who carried similar ethnobotanical surveys in Nigeria. Aguoru and Ogaba, (2010) reported that Bambusa vulgaris, Mangifera indica, Ananas comosus, Carica papaya, Ocimum gratissimum, Azadirachta indica, Psidium guajava, Citrus aurantifolia, and Moringa oleifera were used in the treatment of typhoid amongst the Idoma people of Benue state. Halimat et al., 2017 also reported that Mangifera indica, Alstonia boonei, Ananas comosus, Carica papaya, Ocimum gratissimum, Azadirachta indica, Psidium guajava, Sarcocephalus latifolius, Citrus aurantifolia, Citrus paradisi, and Zingiber officinale were used in the treatment of typhoid in Minna, Niger State. Another study carried out by Sodipo and Wannang, (2015) in Jere Local Government Area of Borno State showed that Azadirachta indica and Citrus aurantifolia were also mentioned.

The result has also shown that leaves, the bark of the trees were mostly used. The leaves of these plants were used singly or in combination with other herbal materials in the fresh or dried forms which are either in the combination of other herbal roots, flowers, and gum of other plant species Table 2. The mode of application is mostly oral by drinking the extracts or concoctions or vapor bathing. However, the dosage levels and the quantities harvested at a time are not measured.. The treatment could be repeated till the person be treated is healed

The development of tourist capacities based on natural resources is a long-term process.

Therefore, the evaluation of ethnobotanical surveys becomes very important. Sustainable tourism represents a type of approach that incorporates within itself the preservation an $d$ enhancement of natural resources and increases the value of local cultural characteristics and traditions. Thus this survey will of ethnobotanical medicinal herbs is very vital medicinal plants are widely accepted by Nigerians and most residents depend on them for a livelihood (Onimhawo, et ai, 2014)

Tourism developed based on medicinal herb increasingly popular in several developed countries, especially as a part of alternative medicine. This results in a growing demand for medicinal herbs, which, in consequence, may lead to excessive use of this resource in natural habitats and, consequently, to the extinction of some species (Ratknić et al., 2011).

The abundance of medicinal and related species, represented in the diverse flora of the Omo forest reserve, offers large possibilities for their rational use. However, careless, irresponsible, and, most frequently, unskilled collection of wild medicinal herbs in the last few decades has contributed to the destruction and excessive reduction of numerous valuable species in their natural habitats. This also may be due to the lack of participation of interested parties in the decision-making process. (Samardžić, 2014). 
The local population that collects herbs for sale most commonly receives financial compensation for the unprocessed herb material. Most wild species, medicinal species, in particular, are still to be collected in the wilderness, which means that it is very huge potential when sustainable development practiced

\section{Conclusion and recommendation}

The research has shown that southwest Nigeria has a great potential for plant species used to treat malaria and typhoid fever. Health and wellness tourism has grown throughout the world and includes the consumption of much traditional medicine. Owing to its medicinal history, India and Nigeria has significant potential for promoting traditional medicine as a consumer product for local consumption, as an export product, and as a tourism resource. It is clearly one of the most important elements of these countries intangible heritagescape that is worthy of additional consideration by tourism developers. Based on this research study many local residents can establish herbal gardens that will enhanced a sense of familiarity with local biodiversity and its conservation, especially herbal plants. The traditional use of herbal health remedies will provides significant nutritional, economic, and ecological benefits for rural communities through tourism. Environmental and management problems are imminent such as deforestation barking of trees, defoliation of plant leaves, and overexploitation, hence efforts should be made to educate the residents on the sustainable harvest. Efforts management plans should be set up to train loal residents on the need to cultivate most of these plants around their homes and farms to reduce damages done to the forest reserve The government should set up a mechanism to integrate alternate medicine which is the use of wild herbs with orthodox medicine. This will improve the sustainable use of these wild plants and create an efficient method of collecting extract from the plant species. It is also common knowledge that the safety of most herbal products is further compromised by lack of suitable quality controls, inadequate labeling, and the absence of appropriate patient information

\section{Acknowledgements}

The authors are very grateful to the staff and management of Ogun State Ministry Of Agriculture South Western Nigeria for their support during the period of the research.

\section{References}

Ambrose, T., \& Paine, C. (Eds.). (2006). Museum Basics. London: Routledge.

Adekunle M.F. (2008). Indigenous uses of plant leaves to treat malaria fever at Omo Forest reserve (OFR) Ogun state, Nigeria Ethiopia Journal of Environmental Studies and Management. 1, (1). 
Adekunle, M.F. (1998). Survey of nontimber forest products (NTFPS) and their uses in Omo forest reserve.Ogun state, Nigeria. Master of Forestry (MF) Unpublished Thesis, Department of Forestry and Wildlife Management, University of Agriculture, Abeokuta, Nigeria.

Aguoru, C. \& Ogaba, J. (2010). Ethonobotanical Survey of Anti-Typhoid Plants Amongst the Idoma People of Nigeria. International Science Research Journal, 2, 34-40.

Amjad, M.S., Faisal Qaeem, M., Ahmad, I., Khan, S.U., Chaudhari, S.K., Malik, N.Z., Shaheen, H. \& Khan, A.M. (2017). Descriptive study of plant resources in the context of the ethnomedicinal relevance of indigenous flora: A case study from Toli Peer National Park, Azad Jammu and Kashmir, Pakistan. PloS one, 12, $\mathrm{e} 0171896$

Awesome, P. O., Ezenwenyi, J. U. (2014). Crown diameter prediction models for Tectona grandis Linn. F. in Omo Forest Reserve, Nigeria. J Forestry Res Manag. $11,72-87$.

Benfield, R. W. (2013). Garden Tourism. Wallingford: CABI.

Benson, A. (2005). Research tourism: Professional travel for useful discoveries. In M. Novelli (Ed.) Niche Tourism: Contemporary Issues, Trends and Cases (pp. 131142). Oxford: Elsevier.

Berdzenishvili, T., Abesadze, A., Arabidze, M., \& Cotoidze, P. (2013, November). Agro-tourism infrastructure development and personnel training project in Kakheti-Alvani-Mtatusheti region. In 8th Silk Road International Conference 'Development of Tourism in Black and Caspian Seas Regions'.

Bodeker C., Bodeker G., Ong C. K., Grundy C. K., Burford G., Shein K. (2005). WHO Global Atlas of Traditional, Complementary and Alternative Medicine. Geneva, Switzerland: World Health Organization [Google Scholar] [Ref list]

Butthongdee, U. (2015). Sustainable tourism development planning in Klong-Blab village, Surat Thani Province, Thailand. International Journal of Social Sciences, $4(3), 20-29$.

Canadian Tourism Commission. (2001). Learning travel: 'Canadian ed ventures' learning vacations in Canada: An overview. Toronto: Author.

Chambers, D., \& McIntosh, B. (2008). Using authenticity to achieve competitive advantage in medical tourism in the English-speaking Caribbean. Third World Quarterly, 29(5), 919-937.

Connell, J. (2013). Contemporary medical tourism: Conceptualisation, culture and commodification. Tourism Management, 34, 1-13. 
Connie, V. \& King, R. (2003). An introduction to Ethnobotany. Shaman Pharmaceuticals Inc.

Cox, P. A. (2005). The seven pillars of ethnomedical wisdom. Ethnobotany, 17, 24-34.

Cole IB, Saxena PK, Murch SJ. Medicinal biotechnology in the genus scutellaria. In Vitro Cell Dev Plant. 2007;43:318-327. doi: 10.1007/s11627-007-9055-4

Deka, B. P., Borgohain, R., \& Bharali, D. (2015). Prospects of herbal gardens as new vistas of medical tourism in North East India. Annals of Pharmacy and Pharmaceutical Sciences, 6(1/2), 46-49.

Diallo, D., Hveem, B., Mahmoud, M.A., Berge, G., Paulsen, B.S., Maiga, A. (1999). An ethnobotanical survey of herbal drugs of Gourma district, Mali. Pharm. Biol, $37,80-91$.

Donaldson, R., \& Gatsinzi, J. (2005). Foreign students as tourists: Educational tourism, a market segment with potential Africa Insight, 35(3), 19-24.

Dzida, K., Zawiślak, G., \& Popławska, Z. (2014). The importance of herbal gardens and the possibility of using herbal plants on an agro-tourist farm in the opinion of the potential recipients of agro-tourism. Annales Universitatis Mariae CurieSkłodowska: Sectio E, Agricultura, 69(1), 34-43.

Enabulele, O. \& Awunor, S.N. (2016). Typhoid fever in a Tertiary Hospital in Nigeria: Another look at the Widal agglutination test as a preferred option for diagnosis. Nigerian Medical Journal: Journal of the Nigeria Medical Association, 57, 145149.

Falodun, A. (2010). Herbal medicine in Africa-distribution, standardization and prospects. Research Journal of Phytochemistry, 4, 154-161.

Gogoi, S., \& Balaji, P. D. (2015). Educational tourism and its impact: A case study from Kanchipuram, Chennai, India. The Clarion, 4(2), 112-115.

Hallmann, K., Müller, S., Feiler, S., Breuer, C., \& Roth, R. (2012). Suppliers' perception of destination competitiveness in a winter sport resort. Tourism Review, 67(2), 13-21.

Halimat, A., Abdulkarim, A., Najma, I., Audu, O.I. and Mohammad, C.D. (2017). An Ethno botanical Survey of Medicinal Plants Used for the Treatment of Typhoid Fever in Minna, Niger State. Journal of Natural Sciences Research 7(8).

Hamilton, A. (2003). Medicinal plant and conservation: issues and approaches. UK: WWF.

Harvey, A.L., Edrada-Ebel, R. \& Quinn, R.J. (2015). The re-emergence of natural products for drug discovery in the genomics era. Nature Reviews Drug Discovery, $14,111$. 
Ijaz, F., Iqbal, Z., Rahman, I.U., Alam, J., Khan, S.M., Shah, G.M., Khan, K. \& Afzal, A. (2016). Investigation of traditional medicinal floral knowledge of Sarban Hills, Abbottabad, KP, Pakistan. Journal of Ethnopharmacology, 179: 208-233.

Igberaese \& Ogbole/Nig.J.Pharm. Res. 2018, 14 (2):175-188.

IGBERAESE and OGBOLE (2018). Ethno botanical survey of plants used in the treatment of typhoid and its complication(s) in esan north east local government area, Uromi, Edo State. Nig.J.Pharm. Res. 2018, 14 (2),175-188.

Isichei (2005). Omo Biosphere Reserve, Current Status, Utilization of Biological Resources and Sustainable Management (Nigeria) Working Papers of the SouthSouth Cooperation Programme on Environmentally Sound Socio-Economic Development in the Humid Tropics. UNESCO, Paris.

Jolliffe, L. (Ed.). (2014). Spices and tourism: Destinations, attractions and cuisines, Bristol: Channel View Publications.

Kala, C. P. (2015). Medicinal and aromatic plants: Boon for enterprise development. Journal of Applied Research on Medicinal and Aromatic Plants, 2(4), 134-139.

Khan, A.U. (2002). History of decline and present status of natural tropical thorn forest in Punjab. Pak. Biol. Conserv. 63, 210-250.

Kazemi, M. (2006). Management of Tourism, Samt, Tehran. Priest, L. (2007). Long wait forces cancer patient to buy operation in land he fled. The Globe and Mail.

Kumar, A., Tewari, D. D, Sharma, R., \& Pandey, V. O. (2005). Practices of folk phytoveterinery in Devipatan division, Uttar Pradesh. Ind. J. Nactcon, 17 (1), 153161.

Lipmann G.S., Eiffing K.P., Ellis MA. Gaudio FG, OTEN, EM AND GRISSOM CK (2014). Wilderness medical society practice guidelines for the prevention and treatment of heart $=$ related illness.

Mahachi-Chatibura, D. (2016). Local cuisine as a potential tourism attractor and marker of national identity in Botswana. Journal of Gastronomy and Tourism, 2(2), 117-134.

Marcy J, Balunasa A, Kinghornb D. Drug discovery from medicinal plants. Life Sci. 2005;78:431-441. doi: 10.1016/j.lfs.2005.09.012

Mengistu, S. (2007). Application of remote sensing and GIS inland use/land cover mapping and change detection in a part of south western Nigeria. African Journal of Environmental Science and Technology 1, 099-109.

Muriuki, J. (2006). Forests as pharmacopoeia: identifying new plant based treatments for malaria. Unasylva 224, 57, 24-25. 
Mukherjee P. W. (2002). Quality Control of Herbal Drugs: An Approach to Evaluation of Botanicals. New Delhi, India: Business Horizons Publishers [Google Scholar] [Ref list

Newman, D.J., Cragg, G. \& Snader, K.M. (2000). The influence of natural products upon drug discovery. Nat. Prod. Rep., 17, 175-285.

Nolan, J. M., \& Schneider, M. J. (2011). Medical tourism in the backcountry: Alternative health and healing in the Arkansas Ozarks. Signs: Journal of Women in Culture and Society, 36(2), 319-326.

Ohe, Y., Ajanovic, E., Caber, M., \& Yilmaz, Y. (2014, December 9-12). Educational tourism in farmyard and successor's identity: Evidence from Japan. In International Antalya hospitality tourism and travel research conference proceedings (pp. 416427). Antalya: Tourism Faculty, Akdeniz University.

Okosodo, EF., Orimaye, J. O., \& Ogunyemi, O. O. (2016). Habitat effects on avian species abundance and diversity in idanre forest reserve south western nigeria. International Journal of Plant, Animal and Environmental Sciences, 6, (3), 1-18.

Onimhawo, J.A. \& Ebhomienlen, T.O. (2014). Esan Traditional Medicine: Problems and Prospects. International Journal of Advancements in Research \& Technology, 3,2 .

Pan, S.Y., Litscher, G., Gao, S.H., Zhou, S.F., Yu, Z.L., Chen, H.Q., Zhang, S.F., Tang, M.K., Sun, J.N. \& Ko, K.M. (2014). Historical Perspective of Traditional Indigenous Medical.

Practices: The Current Renaissance and Conservation of Herbal Resources. Evidencebased Complementary and Alternative Medicine : eCAM, 2014: 525340.

Petrovska, B.B. (2012). Historical review of medicinal plants' usage. Pharmacognosy reviews, 6.

Principe, P. (1991). Monetizing the pharmacological benefits of plants. US Environmental protection Agency, Washington, D.C.

Ratknić, M., Braunović, S., Ratknić, T. (2011): Sustainable use medical herb resourcesapart of Natural park „Stara planina“ tourism development, U Tematskom zborniku -VI Međunarodni naučni skup „Turizam i ruralni razvoj - savremene tendencije, problemii mogućnosti razvoja, 471-477.

Rafieian-Kopaei M. (2013). Medicinal plants and the human needs. J Herb Med Pharm, 1(1-2). [Google Scholar] 17.

Ritchie, B. W., Carr, N., \& Cooper, C. (Eds.). (2003). Managing educational tourism. Clevedon: Channel View Publications 
Rokaya, M.B., Uprety, Y., Poudel, R.C., Timsina, B., Münzbergová, Z., Asselin, H., Tiwari, A., Shrestha, S.S. \& Sigdel, S.R. (2014). Traditional uses of medicinal plants in gastrointestinal disorders in Nepal. Journal of Ethnopharmacology, 158, 221-229

Routledge. Urabe, K. (1988). Innovation and the Japanese management system. In J. Child, T. Kagono, \& K. Urabe (Eds.), Innovation and management, international comparisons (pp. 3-25), New York, NY: de Gruyter.

Sadrmomtaz, N., \& Agharahimi, Z. (2010). Medical tourism in Iran; guidelines for development. Management of Health Information, 7, 516-524.

Sajamski grad, Trebinje, Republika Srpska Rokaya, M.B., Uprety, Y., Poudel, R.C., Timsina, B., Münzbergová, Z., Asselin, H., Tiwari, A., Shrestha, S.S. and Sigdel, S.R. (2014). Traditional uses of medicinal plants in gastrointestinal disorders in Nepal. Journal of Ethnopharmacology, 158, 221-229.

Schmincke, K. (2009). Medicinal Plants for forest conservation and healthcare. Nonwood forest products, 11.

Samardžić, I. (2014): Limitations in development of planned and alternative types of tourism in the "Stara planina" nature park and tourist region, Bulletin of the Serbian Geographical Society, 94(2), 15-23.

Sharma, A. (2013). Medical tourism: Emerging challenges and future prospects. International Journal of Business and Management Invention, 2(1), 21-29.

Sofowora, A. (2013). Medicinal Plants and Traditional Medicine in Africa, Chichester: John Wiley and Sons.

Sodipo, O. \& Wannang, N. (2015). Ethno pharmacological survey of plants used by trado-medical practitioners (TMPs) in the treatment of typhoid fever in Gomari Airport Ward, Jere local government area, Borno State, Nigeria. American Journal of Ethno medicine, 2.

Srujana, ST., Babu KR., Rao BSS. (2012). Phytochemical investigation and biological activity of leaves extract of plant Boswellia serrata. Pharm Innov. 1, 22-46.

Timothy, D. J. (Ed.). (2016). Heritage cuisines: Traditions, identities and tourism, Abingdon.

Timothy, D. J. (2011). Cultural heritage and tourism: An introduction. Bristol: Channel View Publications.

Weldegerima, B. (2009). Review on the importance of documenting ethnopharmacological information on medicinal plants. African journal of Pharmacy and Pharmacology, 3, 400-403. 
World Health Organization, (2005). National policy on traditional medicine and regulation of herbal medicines: report of a WHO global survey. Geneva,

WHO (2008). Typhoid vaccines: WHO position paper=Vaccins antityphoïdiques: note d'information de l'OMS. Weekly Epidemiological Record= Relevé épidémiologique hebdomadaire, 83, 49-59.

WHO (2013). WHO Traditional Medicine Strategy 2014-2023. Zlatković, B.K., Bogosavljević, S.S., Radivojević, A.R. \& Pavlović, M.A. (2014). Traditional use of the native medicinal plant resource of Mt. Rtanj (Eastern Serbia): Ethnobotanical evaluation and comparison. Journal of Ethnopharmacology, 151, 704-713.

WHO (2014). Typhoid vaccines: WHO position paper= Vaccins antityphoïdiques: note d'information de l'OMS. Weekly Epidemiological Record= Relevé épidémiologiquehebdomadaire, 83, 49-59. 